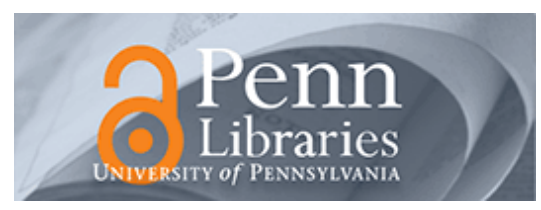

Manuscript Studies

Volume 5 | Issue 2

Article 3

2021

\title{
The Roaring Lion and the Horse of God: The Enigma of the Evangelist Portraits in the Harkness Gospels (New York Public Library, MA 115)
}

Violetta Barbashina

Fordham University, vbarbashina@fordham.edu

Follow this and additional works at: https://repository.upenn.edu/mss_sims

Part of the Ancient, Medieval, Renaissance and Baroque Art and Architecture Commons, and the Medieval Studies Commons

\section{Recommended Citation}

Barbashina, Violetta (2021) "The Roaring Lion and the Horse of God: The Enigma of the Evangelist Portraits in the Harkness Gospels (New York Public Library, MA 115)," Manuscript Studies: Vol. 5 : Iss. 2 , Article 3.

Available at: https://repository.upenn.edu/mss_sims/vol5/iss2/3

This paper is posted at ScholarlyCommons. https://repository.upenn.edu/mss_sims/vol5/iss $2 / 3$

For more information, please contact repository@pobox.upenn.edu. 


\title{
The Roaring Lion and the Horse of God: The Enigma of the Evangelist Portraits in the Harkness Gospels (New York Public Library, MA 115)
}

\author{
Abstract \\ This paper addresses the question of sources for the idiosyncratic representations of the Evangelists \\ created by ninth-century Breton monks and explores what might have prompted the occasional \\ substitution of the horse for the traditional symbol of Saint Mark, the lion. Challenging the assumption of \\ a "Celtic" connotation of equine imagery, this study suggests that the monks were directly influenced by \\ Gregory the Great's allegorical interpretation of the horse given in the Moral Reflections on Job 39. \\ Echoing Gregory as he draws a parallel between the emblematic qualities of the horse (strength, \\ perseverance, courage) and those required of a servant of God, the innovative iconography of Saint Mark \\ unites the lion and the horse in celebratory remembrance of Christ's sacrifice and resurrection and \\ glorifies in the image of the Evangelist the tireless preacher, the devoted and fearless Horse of God.
}

\section{Keywords}

Manuscript studies, evangelist symbols, "beast-headed" portraits, evangelist portraits, breton gospel illumination, landevennec gospels 


\section{MANUSCRIPT STUDIES}

A Journal of the Schoenberg Institute for Manuscript Studies

VOLUME 5, NUMBER 2

(Fall 2020)

Manuscript Studies (ISSN 2381-5329) is published semiannually

by the University of Pennsylvania Press

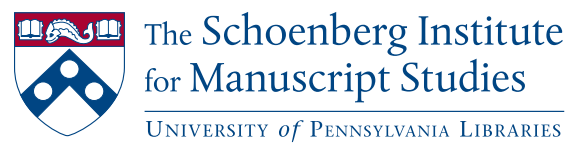




\title{
MANUSCRIPT STUDIES
}

V O L U M 5, N U M B R 2

(Fall 2020)

ISSN 2381-5329

\begin{abstract}
Copyright (c) 2020 University of Pennsylvania Libraries and University of Pennsylvania Press. All rights reserved.

Published by the University of Pennsylvania Press, 3905 Spruce Street, Philadelphia, PA 19104.
\end{abstract}

Printed in the U.S.A. on acid-free paper.

Manuscript Studies brings together scholarship from around the world and across disciplines related to the study of premodern manuscript books and documents, with a special emphasis on the role of digital technologies in advancing manuscript research. Articles for submission should be prepared according to the Chicago Manual of Style, $16^{\text {th }}$ edition, and follow the style guidelines found at http://mss.pennpress.org.

None of the contents of this journal may be reproduced without prior written consent of the University of Pennsylvania Press. Authorization to photocopy is granted by the University of Pennsylvania Press for libraries or other users registered with Copyright Clearance Center (CCC) Transaction Reporting Service, provided that all required fees are verified with CCC and paid directly to CCC, 222 Rosewood Drive, Danvers, MA 01923. This consent does not extend to other kinds of copying for general distribution, for advertising or promotional purposes, for creating new collective works, for database retrieval, or for resale.

2020 SUBSCRIPTION INFORMATION:

Single issues: $\$ 30$

Print and online subscriptions: Individuals: \$40; Institutions: \$94; Full-time Students: \$30 International subscribers, please add $\$ 19$ per year for shipping.

Online-only subscriptions: Individuals: $\$ 32$; Institutions: $\$ 82$

Please direct all subscription orders, inquiries, requests for single issues, address changes, and other business communications to Penn Press Journals, 3905 Spruce Street, Philadelphia, PA 19104. Phone: 215-573-1295. Fax: 215-746-3636. Email: journals@pobox.upenn.edu. Prepayment is required. Orders may be charged to MasterCard, Visa, and American Express credit cards. Checks and money orders should be made payable to "University of Pennsylvania Press" and sent to the address printed directly above.

One-year subscriptions are valid January 1 through December 31 . Subscriptions received after October 31 in any year become effective the following January 1. Subscribers joining midyear receive immediately copies of all issues of Manuscript Studies already in print for that year.

Postmaster: send address changes to Penn Press Journals, 3905 Spruce Street, Philadelphia, PA 19104.

Visit Manuscript Studies on the web at mss.pennpress.org. 


\title{
The Roaring Lion and the Horse of God: The Enigma of the Evangelist Portraits in the Harkness Gospels (New York Public Library, MA 115)
}

\author{
VIOLETTA BARBASHINA \\ Fordham University
}

"In the idiom of monasticism, people do not 'have' ideas, they 'make' them."

-Mary Carruthers, The Craft of Thought:

Meditation, Rhetoric, and the Making of Images, 400-1200

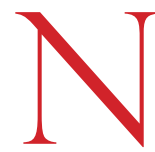

ew York Public Library (NYPL), MA 115, known as the Harkness Gospels, belongs to a small group of illuminated Latin Gospel books remarkable for their rudimentary yet expressive drawings and unorthodox iconography that were produced in Lower Brittany, at and around the monastery of Landévennec, at the turn of the ninth and tenth centuries. ${ }^{1}$ A recurrent element in the decoration of these books

I am grateful to Susanne Hafner and Nina Rowe for their comments and to the anonymous reviewer for additional suggestions for improvement. My sincere thanks to the New York Public Library, the Municipal Library of Boulogne-sur-Mer, and Thomas J. Watson Library of the Metropolitan Museum of Art for permission to use their resources.

1 In addition to NYPL MA 115, the list of manuscripts firmly attributed to the Landévennec scriptorium includes Oxford, Bodleian Library, MS Auct. D.2.16 (Gospels, late 9th-early 10th 
is the presence of portraits of the Evangelists shown as composite creatures with human bodies but with heads of the respective celestial symbols associated with each (figs. 1-3). Soon after its acquisition by the NYPL in 1928, the Harkness manuscript was studied by an expert group of philologists, historians, and art historians led by Charles R. Morey, Edward K. Rand, and Carl H. Kraeling, who commented on its many unusual features. The resulting report published in 1931 offered the first comprehensive scholarly analysis of this early Breton Gospel book. ${ }^{2}$ From the time of its release to about the mid-1980s, little was added to the original assessment aside from brief commentaries on the pictorial decoration of the manuscript. Among the latter, however, one should specifically mention the contributions of René Crozet and Jeanne Laurent, whose remarks on the strangely ambiguous features of Mark's symbol in the Landévennec productions continue to animate art historical discussion. ${ }^{3}$

century); Copenhagen, Kongelige Bibliotek, Thott 239 (liturgical calendar, first half of the 10th century); Cambridge, Corpus Christi College, MS 192 (Amalarius of Metz, Liber officialis, 952); and Quimper, Bibliothèque municipale, MS 16 (cartulary preserving ninth-century hagiographical texts, 11th century)/Paris, Bibliothèque nationale de France, MS lat. 5610A (hagiographical texts only, late 10th-early 11th century). Three more manuscripts hailing from Brittany, though not necessarily from Landévennec, are often added to the "Landévennec group" based on stylistic and iconographic similarities; these are Bern, Burgerbibliothek, Cod. 85 (Gospels, second half of the ninth century); Troyes, Bibliothèque municipale, MS 960 (Gospels, 909); and Boulogne-sur-Mer, Bibliothèque municipale, MS 8 (Gospels, second half of the ninth century). See Jean-Luc Deuffic, "La production manuscrite des scriptoria bretons (VIII ${ }^{\mathrm{e}}-\mathrm{XI}{ }^{\mathrm{e}}$ siècles)," in Landévennec et le monacbisme breton dans le Haut Moyen Âge: Actes du Colloque du $15^{\mathrm{eme}}$ centenaire de l'abbaye de Landévennec, 25-27 April 1985 (Association Landévennec, 1986), 289-321; Helen Simpson McKee, "Breton Manuscripts of Biblical and Hiberno-Latin Texts," in The Scriptures and Early Medieval Ireland: Proceedings of the 1993 Conference of the Society for HibernoLatin Studies on Early Irish Exegesis and Homiletics, ed. Thomas O'Loughlin (Turnhout: Brepols, 1999), 275-90; Louis Lemoine, "Breton Early Medieval Manuscripts," in Celtic Culture: A Historical Encyclopedia, ed. John Koch, 5 vols. (Santa Barbara, CA: ABC-CLIO, 2006), 254-59.

2 Charles R. Morey, Edward K. Rand, and Carl H. Kraeling, The Gospel Book of Landévennec (The Harkness Gospels) (Cambridge, MA: Harvard University Press, 1931). A selection of digitized images from NYPL MA 115 is accessible through the Digital Scriptorium at http://www. digital-scriptorium.org and the NYPL Digital Collections at https://digitalcollections.nypl.org. 3 René Crozet, "Les représentations anthropo-zoomorphiques des évangélistes dans l'enluminure et dans la peinture murale aux époques carolingienne et romane," Cabiers de civilisation médiévale 1 (1958): 182-87; Jeanne Laurent, Bretagne et Bretons (Paris: Arthaud, 1974), 26-31 with figs. 19-22, "Évangélistes à tête de cheval." 


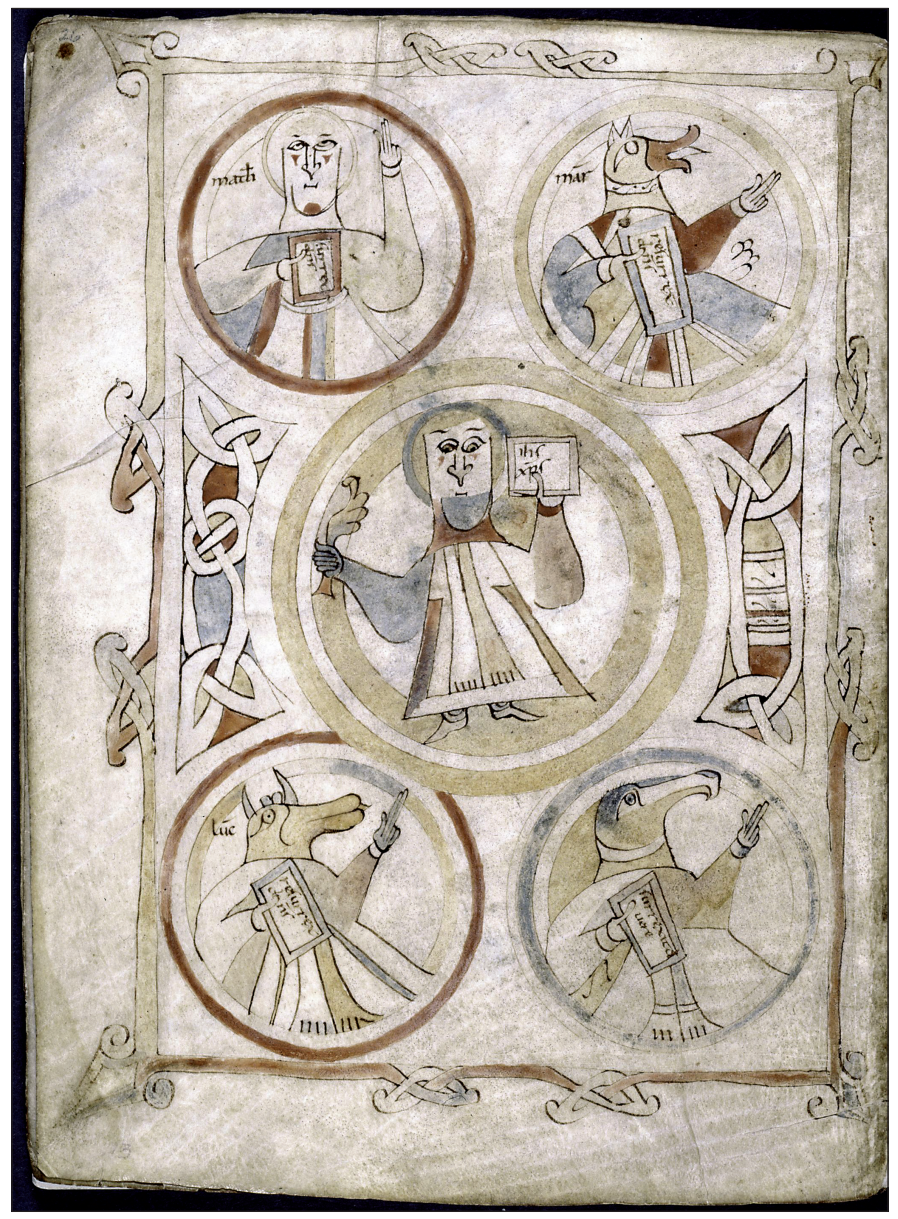

$\oplus$

FIGURE 1. Frontispiece showing Christ and the Evangelists. Harkness Gospels (NYPL MA 115), fol. 13v. Image credit: Renaissance and medieval manuscripts collection. Manuscripts and Archives Division. The New York Public Library. Astor, Lenox, and Tilden Foundations.

Indeed, what strikes the viewer in the images of Mark in MA 115 (see figs. 1, 2a)—and even more so in his portrait in Boulogne-sur-Mer, Bibliothèque municipale, MS 8 , from the same group ${ }^{4}$ (see fig. 3 ) -is that the decorators, while clearly aware of how to properly draw a lion, chose to

$4 \quad$ See note 1. 

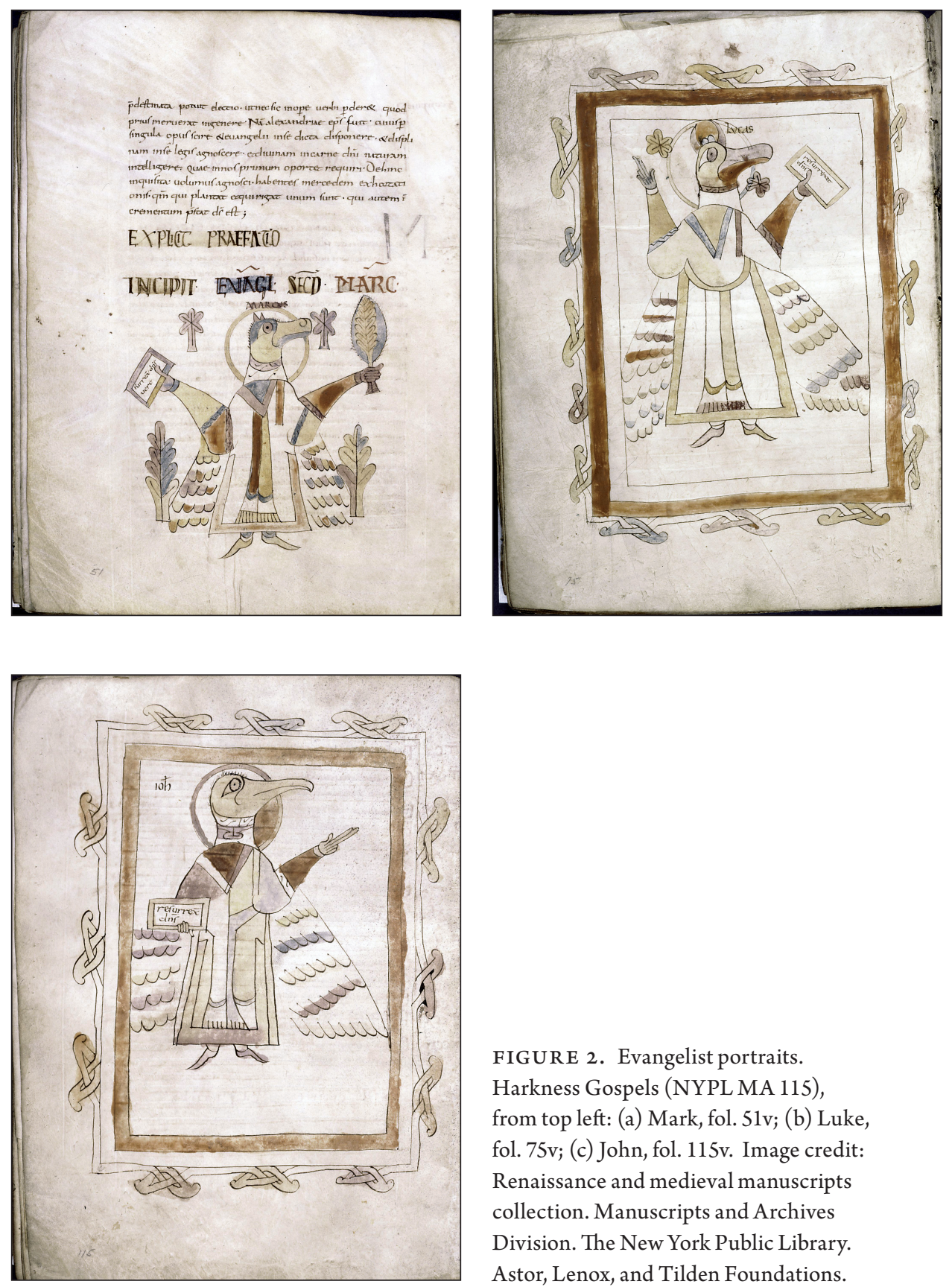

FIGURE 2. Evangelist portraits.

Harkness Gospels (NYPL MA 115), from top left: (a) Mark, fol. 51v; (b) Luke, fol. 75v; (c) John, fol. 115v. Image credit: Renaissance and medieval manuscripts collection. Manuscripts and Archives Division. The New York Public Library. Astor, Lenox, and Tilden Foundations. 
Barbashina: Evangelist Portraits in the Harkness Gospels

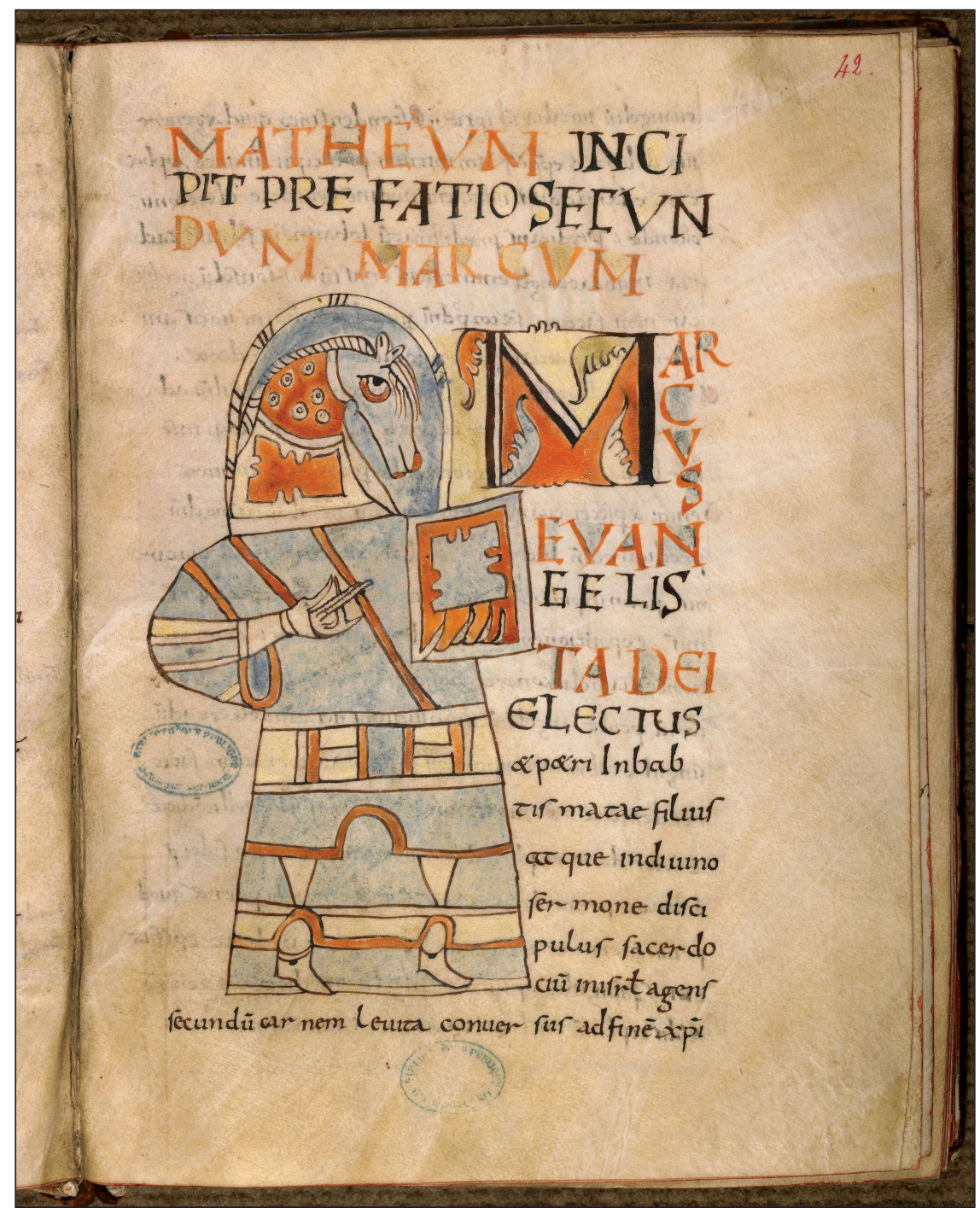

$\oplus$

FIGURE 3. Evangelist Mark. Boulogne-sur-Mer, Bibliothèque municipale, MS 8

(Gospels, Brittany, second half of the ninth century), fol. 42r. Image credit: Bibliothèque municipale de Boulogne-sur-Mer. Bibliothèque virtuelle des manuscrits médiévaux (BVMM)/Institut de recherche et d'histoire des textes (IRHT-CNRS). 
depict a very different kind of animal that to some looks more "horse-like." But why a horse? And what could possibly link this symbolic horse to the Gospel writer? Laurent's idea that the transformation of Mark's lion into a horse was prompted by the similarity in pronunciation of the name Mark and the Breton word for horse, marc'b, has been repeated by others, though somewhat reluctantly and mainly for lack of a better explanation. ${ }^{6}$ Alternative hypotheses focusing largely on a Celtic element with its colorful assortment of mythological and legendary figures, from the dieu-cheval celtique to famous King Mark with horse's ears, are even more tenuous. ${ }^{7}$

5 Laurent, Bretagne et Bretons, 30: "Si nous en venons à Marc, son emblème dans l'école qui nous intéresse ici a été tenu tantôt pour un cheval et tantôt pour un lion. Or, il s'agit toujours d'un cheval. Là où des commentateurs ont vu un lion, nous nous trouvons devant un cheval hennissant" (If we come to Mark, his emblem in the school that interests us here has sometimes been held to be a horse and sometimes a lion. Yet it is always a horse. Where some commentators saw a lion, we find ourselves in front of a neighing horse). Laurent's impression is largely shared by Louis Lemoine, "Le scriptorium de Landévennec et les représentations de Saint Marc," in Mélanges François Kerlouégan, ed. Danièle Conso, Nicole Fick, and Bruno Poulle (Besançon: Université de Besançon, 1994), 363-79; and Michel Huglo, "Les évangiles de Landévennec (New York, Public Library, De Ricci 115)," in Landévennec et le monachisme breton dans le Haut Moyen Âge: Actes du Colloque du $15^{\mathrm{eme}}$ centenaire de l'abbaye de Landévennec, 25-27 April 1985 (Association Landévennec, 1985), 245-49. The NYPL exhibition caption for the image of Mark on fol. 51v of MA 115 reads: "Unusual symbol for Mark: a horse" ("Three Faiths: Judaism, Christianity, Islam," October 2010-February 2011, accessible at http://exhibitions.nypl.org/threefaiths/node/33?highlight=2).

6 Laurent, Bretagne et Bretons, 30.

7 Advanced by Laurent, Bretagne et Bretons, 30, and Lemoine, "Le scriptorium de Landévennec," 369-70. Interest in early Breton manuscript illumination seems to have reignited with the publication of the materials of a landmark conference held on the occasion of the 1,500-year anniversary of Landévennec Abbey: Landévennec et le monachisme breton dans le Haut Moyen Âge: Actes du Colloque du $15^{\text {eme }}$ centenaire de l'abbaye de Landévennec, 25-27 April 1985 (Association Landévennec, 1985). The peculiar imagery employed in the decoration of the "Landévennec group" of manuscripts has since been revisited, yet some of its mysteries-most notably, the occasional substitution of the horse for the traditional symbol of Mark, the lion—remain unsolved; see Marianne Besseyre, "Une iconographie sacerdotale du Christ et des évangélistes dans les manuscrits bretons des IX et $\mathrm{X}^{\mathrm{e}}$ siècles," Pecia: La Bretagne carolingienne. Entre influences insulaires et continentales 12 (2007): 7-26; and Beatrice Kitzinger, "Troyes, Bibliothèque municipale, MS 960: Approaches to Ninth-Tenth Century Breton Gospel Illumination," Rivista di Storia della Miniatura 17 (2013): 29-42. In October 2005-February 2006, the Harkness Gospels were featured in NYPL's exhibition of its little- 
The codex is well preserved and retains nearly all of its original pages. As we can gather from Kraeling's report, "apart from minor mutilations ... [resulting from] the excision of decorative materials ... . [and] the apparent removal of the symbol of Matthew ... there are but two or three leaves of text missing all in all." ${ }^{8}$ Detailed examination of the book's contents reveals a curious mix of Continental and Insular elements, as well as the presence of Breton-type neumes and three liturgical commemorations of Saint Winwaloe, founder and patron saint of the celebrated monastery of Landévennec on the far western coast of Brittany. ${ }^{9}$ Based on the combination of paleographical, textual, and liturgical evidence, the manuscript was definitively localized to the abbey of Landévennec and dated "somewhere in the second half of the ninth century." 10

The structure of MA 115 resembles that of other early medieval Gospel books and emphasizes its liturgical character. In addition to the four Vulgate Gospels, the codex contains a calendar of readings for the liturgical year (Comes) and the usual set of canon tables and prefaces, which serve to underscore the authority and unity of the scriptures and explain the number of the Evangelists and the meaning of their symbols. The book opens

known medieval manuscripts and given an updated description in the accompanying catalog: Jonathan J. G. Alexander, James H. Marrow, and Lucy Freeman Sandler, The Splendor of the Word: Medieval and Renaissance Illuminated Manuscripts at the New York Public Library (New York: NYPL, 2006), 45-50, cat. no. 6.

8 Morey, Rand, and Kraeling, The Gospel Book of Landévennec, 17.

9 The usual French form of the saint's name is St. Guénolé. The modern Breton form is Gwennole. In the British Isles, he is commonly known as St. Winwaloe, or St. Winwalloc. But as Morey has indicated, "between these the range of variation is extensive-Wingaloeus, Winwolaus, Walory, Guingaloeus, Gwinualoer, Guingaloe, Guingaloi, Gunwallow; ... the parish-church of Portlemouth, in Devon, is dedicated to the saint under the name St. Onolaus"; Morey, Rand, and Kraeling, The Gospel Book of Landévennec, 54-55.

10 Morey, Rand, and Kraeling, The Gospel Book of Landévennec, 4. While a more precise dating within this period has proven problematic, the terminus ante quem is generally accepted as 913 , the year of the devastating Viking raid on the monastery. Some scholars believe that the work was executed closer to the last quarter of the ninth century; see, for example, K. D. Hartzell, "The Early Provenance of the Harkness Gospels," Bulletin of Research in the Humanities 84 (1981): 85-97, 92 n. 10. The NYPL exhibition catalog gives a somewhat broader date: late ninth to early tenth century (Alexander, Marrow, Sandler, The Splendor of the Word, 45). 
with four traditional general prologues (Jerome's Novum opus; a short passage of uncertain authorship [Sciendum etiam] explaining the use of the canon tables, the letter of Eusebius to Carpianus [Ammonius quidam], and Jerome's introduction to his Commentary on Matthew [Plures fuisse]), which are followed by the prefaces to the individual Evangelist accounts (Argumenta) and chapter listings (Capitula). In the margins of the Gospels, there are lection marks for the liturgy.

The ornamentation of MA 115 is vigorous but not luxurious. Commenting on the text decoration, Edward K. Rand remarked, "There is no splendor anywhere. Irish and Continental motifs commingle in rather primitive designs." 11 The four surviving miniatures depicting Christ and the Evangelists are similarly unassuming, represented by simplified line drawings with color washes and minimal adornment. The palette is limited to yellow, red, blue, and purple (the latter obtained "by mixing the red and blue"); there is no evidence of gold or silver decoration. ${ }^{12}$ The relative simplicity of execution suggests that the book was intended for practical use-quite possibly, for internal use in the daily cycle of communal and private prayer-and not as a display copy. ${ }^{13}$

The unusual designs of the Harkness Gospels' miniatures have long attracted scholarly interest, but until fairly recently, the focus has been mainly on their clumsy shapes and poor, provincial quality. The plainlooking, semi-abstract creations, startlingly different from the sumptuous and classicizing Carolingian illuminations, were long regarded as naïve and archaistic, while the persisting preference for the schematic over the naturalistic was attributed to backwardness, lack of resources, and reliance on

11 Morey, Rand, and Kraeling, The Gospel Book of Landévennec, 9.

12 Quote from Morey, Rand, and Kraeling, The Gospel Book of Landévennec, 36. Alexander, Marrow, and Sandler, The Splendor of the Word, 48-49.

13 Other indicators similarly point to the largely utilitarian purpose of the project. In summing up the results of his analysis, Kraeling remarked, "Certainly, the large amount of scribal error ... [reveals] that we are not dealing with the work of a professional or professionals but with the work of men who undertook their task by reason of some immediate necessity, such as the need for a second copy of Scripture." Morey, Rand, and Kraeling, The Gospel Book of Landévennec, 34-35. 
outdated models. ${ }^{14}$ More recently, Jonathan J. G. Alexander has tried to present Landévennec art in a more positive light, arguing that the adherence to simplified forms might have been a product of deliberate choice rather than any constraints, a conscious "refusal" of Carolingian aesthetics, "in line with the resistance to both political and cultural domination." 15 Perhaps surprisingly, there has been little discussion of what the monks tried to communicate by particular designs or how the images might have functioned for their intended, presumably monastic, audience. Yet, judging by the prominence and singularity of the illuminations, one can assume that they were meant to be "used" by the monks.

The functional or, more specifically, the cognitive dimension of images has interested monastics since early times. ${ }^{16}$ Monastic and patristic sources spoke of the images' utility for meditation, specifically pointing to their mnemonic role and their potential to stimulate associative memory and facilitate the reader's absorption of biblical concepts. ${ }^{17}$ The images had the unique capacity to combine information from varied authoritative sources and highlight the key elements to make the intended message clearer. Accustomed to using imagery for memorization and meditation purposes, the monastics long recognized that adding an element of surprise-be it a visual paradox, an allegory, or its more obscure variant, an enigma-increased the effectiveness of an ornament as a cognitive tool, for such devices rely on emotion, and emotion, as pointed out by Mary Carruthers, is "the quickest and surest way to catch the mind's attention." ${ }^{18}$

14 Morey, Rand, and Kraeling, The Gospel Book of Landévennec, 39-40; Geneviève MarshMicheli, L'Enluminure du baut Moyen Âge et les influences irlandaises (Brussels: Édition de la Connaissance, 1939), 98-99; Crozet, "Les représentations anthropo-zoomorphiques des évangélistes," 184.

15 Jonathan J. G. Alexander, Medieval Illuminators and Their Methods of Work (New Haven, CT: Yale University Press, 1992), 82. Alexander, "La résistance à la domination culturelle carolingienne dans l'art breton du IX siècle: le témoignage de l'enluminure des manuscrits," in Landévennec et le monachisme breton, 269-80 at 271.

16 Discussed in detail by Mary Carruthers, The Craft of Thought: Meditation, Rhetoric, and the Making of Images, 400-1200 (Cambridge: Cambridge University Press, 1998), 116-70.

17 Carruthers, The Craft of Thought, 118-22.

18 Carruthers, The Craft of Thought, 117. 
Assuming that the miniatures in MA 115 were intended as visual anchors for the monks to use in meditative and communal prayer, I will focus on their two most striking, and perhaps related, features-the liturgical character of the compositions and the ambiguity of the symbol of Mark - and will attempt to deduce the intent of the iconography with the assistance of pertinent textual sources. I aim to show that the allusions to the horse and the emphasis on the symbolism of the liturgy become less of an enigma if one recalls that the imagery comes from Christian writers by whom the monks lived. What makes the Landévennec compositions stand out, I argue, is their extensive and imaginative use of allegory-likely inspired by biblical and liturgical commentaries and employed as a cognitive device - which points us in the direction of rich exegetical literature, by far the most popular reading material in early medieval monasteries. In the following analysis, I focus on two major Christian commentators, Gregory the Great (ca. 540-604) and Amalarius of Metz (ca. 775-850), and attempt to read the miniatures through the prism of allegorical interpretations provided in Gregory's and Amalarius's works. The selection of sources has been guided by three principles: the material is presumed to have been available to the artists, it is deemed "indispensable for understanding unusual features" of the illuminations, and it is certain to have been familiar to the original intended audience. ${ }^{19}$

\section{Landévennec Abbey and Its Scriptorium in the Late Ninth/Early Tenth Centuries}

At the time when the manuscript was made, near the end of the eventful ninth century, the abbey of Landévennec was at the height of its prosperity and spiritual influence. ${ }^{20}$ The ninth century was a turning point in the

19 As spelled out by Lawrence Nees, “Image and Text: Excerpts from Jerome's 'De Trinitate' and the Maiestas Domini Miniature of the Gundohinus Gospels,” Viator 18 (1987): $1-21$ at 1 .

20 Yves Morice, "L'abbaye de Landévennec des origines au XI" siècle à travers la production hagiographique de son scriptorium: Culture monastique et idéologies dans la Bretagne du 


\section{4 | Journal for Manuscript Studies}

history of Brittany, a period marked by Carolingian expansion into the region, which set off the process of political unification, standardization of monastic observance, revival of learning, and a significant cultural shift. ${ }^{21}$ In 818, following a decree issued earlier that year by the Carolingian emperor Louis the Pious, the abbey of Landévennec abandoned its Celtic customs to become a Benedictine house. ${ }^{22}$ There is no reason to believe that the monks were unhappy about the change; on the contrary, many appear to have thought that adopting a less rigorous rule would be a welcome improvement to their exceedingly strict ascetic organization. ${ }^{23}$ Soon thereafter, the monastery underwent a major structural renovation aimed to bring the house in line with Carolingian standards. Archeological evidence confirms that by the end of the ninth century the community had a new stone basilica, an expanded communal area, and a cloister. ${ }^{24}$ This does not indicate that the long-standing cultural ties with the British Isles were abruptly severed; manuscript evidence documenting the use of insular variants well into the ninth century testifies to the contrary, and so do the contents of MA 115's liturgical calendar. ${ }^{25}$

The period between 850 and 913 witnessed a veritable flourishing of the monastery and its scriptorium. ${ }^{26}$ As far as one can judge by the few surviving manuscripts attributable to Landévennec and datable to the late ninth

Haut Moyen Âge" (Ph.D. diss., Université Rennes 2, 2007), 393.

21 Wendy Davies, Small Worlds: The Village Community in Early Medieval Brittany (London: Duckworth, 1988); Julia M. H. Smith, Province and Empire: Brittany and the Carolingians (Cambridge: Cambridge University Press, 1992); Caroline Brett, "Brittany and the Carolingian Empire: A Historical Review,” History Compass 11 (2013): 268-79.

22 Smith, Province and Empire, 72.

23 Smith, Province and Empire, 72; Morice, "L'abbaye de Landévennec," 392, 398-99, 403405, 409, 411, 414; Chiara Garavaglia and Yves Morice, "Clôture et ouverture: Landévennec et l'ouverture de la Bretagne au domaine culturel carolingien," in Corona Monastica. Moines bretons de Landévennec: bistoire et mémoire celtiques. Mélanges offerts au père Marc Simon (Rennes: Presses universitaires de Rennes, 2004), 19-35.

24 Morice, "L'abbaye de Landévennec," 387-92, 582-83 (Appendix 24: ground plan reconstructions based on archeological data).

25 Morey, Rand, and Kraeling, The Gospel Book of Landévennec, 10-11, 25, 31-33, 51.

26 Morice, “L'abbaye de Landévennec," 393. 
and tenth centuries, the primary purpose of the scribal enterprise was to satisfy local demand for Gospel books and new liturgical material. ${ }^{27}$ But its greatest undertaking was the production of new hagiographies, such as the Vita Amplior of Landévennec's founder Saint Winwaloe, composed by the abbot Wrdisten, and the commissioned Vita of Saint Paul Aurelian, written by the monk Wrmonoc. These late ninth-century works contain references to authoritative texts and a few direct quotations, which have been used by scholars to gain insight into the range of sources available to the hagiographers. ${ }^{28}$ Whereas early Breton manuscripts of patristic literature are remarkably few, the Vitae, as Julia Smith points out, "allow us to see how extensive were the classical and patristic resources available in westernmost Brittany." ${ }^{29}$ The monks were familiar with the works of Gregory the Great, Isidore of Seville, Jerome, Augustine, Cassian, and Cassiodorus, with the collection of early monastic literature known as the Sayings of the Desert Fathers, and with Irish hagiographies (Muirchú's Vita sancti Patricii, Cogitosus's Vita Brigidae, and Adomnán's Vita sancti Columbae). ${ }^{30}$

As part of his doctoral study of the literary production at Landévennec, Yves Morice has looked into the types and frequencies of biblical and literary references occurring in Wrdisten's and Wrmonoc's works, thereby providing a window into the reading and interpretive practices of ninth-century Breton monks. He notes, for example, that the most quoted Gospel texts in the Vitae are Matthew (in Wrdisten) and John (in Wrmonoc), followed by

27 See note 1. The focus on fulfilling the need for good copies of the Gospels and liturgical texts is characteristic of Breton scribal activity of that period; see Smith, Province and Empire, 164-177; and David N. Dumville, "Writers, Scribes and Readers in Brittany, AD 800-1100: The Evidence of Manuscripts," in Medieval Celtic Literature and Society, ed. Helen Fulton (Dublin: Four Courts Press, 2005), 49-64.

28 The Vita Pauli Aureliani was completed in 884, as dated by the author; the Vita Amplior Uuinuualoei was likely written between 857/867 and 884 (Morice, "L'abbaye de Landévennec," 26,67 ).

29 Smith, Province and Empire, 175.

30 Smith, Province and Empire, 174-75; Garavaglia and Morice, "Clôture et ouverture," 19-35; Bernard Merdrignac, "Saint Guénolé et les monachismes insulaire et continental au haut Moyen Âge," Annales de Bretagne et des pays de l'Ouest 95 (1988): 15-40. 
Luke and very little by Mark. ${ }^{31}$ While the Book of Revelation is virtually absent from the Vitae, the prophetic books of the Old Testament do get some attention. ${ }^{32}$ Perhaps predictably, some of the most frequently quoted texts are the Psalms (22 percent in Wrdisten, 26 percent in Wrmonoc). ${ }^{33}$ Among nonbiblical sources, the works of Gregory the Great and Isidore of Seville emerged as clear favorites (14 percent and 12 percent of citations in Wrdisten, respectively). ${ }^{34}$ Gregory was apparently one of Wrdisten's favorite Christian commentators, from whom he amply borrowed. ${ }^{35}$

Gregory the Great perhaps least of all needs an introduction. "Everyone, in fact," writes Jean Leclercq, "had read him and lived by him." ${ }^{6}$ The enormous popularity of his writings among medieval monastics can be explained in part by the fact that the questions he addressed were the ones that the audience continuously wrestled with, and the commentary given was always insightful, rich in allegory, and "eminently conducive to contemplative prayer." ${ }^{37}$ Gregory's method of textual analysis with careful attention to syntactic and semantic clues, the so-called grammatical reading of the Bible, must have been particularly appealing to educated Carolingian readers. ${ }^{38}$ His most widely circulated and quoted texts were the Moralia in Job, Homilies on the Gospels, Dialogues, and Pastoral Care.

Gregory's magnum opus, the Moralia (Moral Reflections on the Book of Job), was understood to be much more than an exposition of the biblical book on Job; it was a book that touched on perennial questions of what it

31 The focus on Matthew and relative invisibility of Mark were characteristic features of patristic exegesis and early medieval lectionary practice; see Derek A. Olsen, Reading Matthew with Monks: Liturgical Interpretation in Anglo-Saxon England (Collegeville, MN: Liturgical Press, 2015), 23; and Brenda Deen Schildgen, Power and Prejudice: The Reception of the Gospel of Mark (Detroit: Wayne State University Press, 1999), 17-84.

32 Morice, "L'abbaye de Landévennec," 164 and fig. 8.

33 Morice, "L'abbaye de Landévennec," 163-64.

34 Morice, "L'abbaye de Landévennec," 190.

35 Morice, "L'abbaye de Landévennec," 161, 195.

36 Jean Leclercq, The Love of Learning and the Desire for God: A Study of Monastic Culture, trans. Catharine Misrahi (New York: Fordham University Press, 2016), 26.

37 Leclercq, The Love of Learning, 183.

38 Mark DelCogliano, introduction to Gregory the Great, Moral Reflections on the Book of Job, trans. Brian Kerns (Collegeville, MN: Cistercian Publications, 2014), 24. 
meant to be a servant of Christ and miles Christi, and that was written by a commentator endowed with great spiritual insight and linguistic sensitivity. From the time of its completion, it was avidly copied, in its entirety or in excerpts, and carefully studied. A rare monastic institution was without access to Gregory's Moralia, at least excerpts from it. ${ }^{39}$ One particular characteristic of Gregory's discourse - the memorable quality of his descriptions due to his masterful use of imagery-should prompt us to take a closer look at his texts when searching for explanations for the unusual iconography.

Another resource of great interest is Amalarius of Metz's Liber officialis (On the Liturgy), a widely read text of the Carolingian era. Unlike the universally revered works of Gregory, the commentaries of Amalarius were in equal measure popular and controversial. ${ }^{40}$ Bishop Amalarius of Metz was a dedicated, scholarly Carolingian writer who was concerned with standardization, elevation, and beautification of the ritual. His major contribution and radical innovation consisted of applying the allegorical method normally reserved for biblical exegesis to the interpretation of the symbolism of the church ritual. In Amalarius's world, as Eric Knibbs explains, every movement, every gesture of the celebrant, every item of liturgical dress has a symbolic significance, with each element telling its part of the story of Christ. ${ }^{41}$

The Liber enjoyed early recognition in Brittany and, while admittedly not proven, it is quite possible that the monks of Landévennec were in possession of Amalarius's book at some point between 850 and $900 .{ }^{42}$ The

39 Lawrence Besserman, The Legend of Job in the Middle Ages (Cambridge, MA: Harvard University Press, 1979), 56. We have no Breton copies of the Moralia from that period. Yet the text was widely available, copied at various Insular foundations on the Continent, at the Carolingian centers (Tours, Fleury), and in other locations. See Jesse Keskiaho, Dreams and Visions in the Early Middle Ages: The Reception and Use of Patristic Ideas, 400-900 (Cambridge: Cambridge University Press, 2015), 104-5 and 236-40 (appendix).

40 As remarked by Eric Knibbs, the attacks launched by Amalarius's opponents had sometimes more to do with personal and political rivalry than with the author's unorthodox methods. Eric Knibbs, introduction to Amalar of Metz, On the Liturgy, ed. and trans. Eric Knibbs (Cambridge, MA: Harvard University Press, 2014), xxii-xxvi.

41 Knibbs, introduction to Amalar of Metz, On the Liturgy, xvii.

42 The earliest extant Breton copy of Amalarius's Liber officialis is Paris, Bibliothèque nationale de France, MS nouv. acq. lat. 1983 (ca. 900), but there may have been earlier copies. See 
earliest known Landévennec-made copy of Amalarius's Liber officialis dates to 952 (Cambridge, Corpus Christi College, MS 192). David N. Dumville believes it to be a copy made from an English exemplar, which in turn had been copied from a Breton manuscript of the ninth century, now lost. ${ }^{43}$

The thoughts on the liturgy and on "spiritual direction both within the ascetic community and in the broader Christian environment" voiced by these two authoritative figures could not but have found responsive ears within a religious community ready to take on a spiritual leadership role in the changing region. ${ }^{44}$

\section{Unlocking the Secrets of the Miniatures: Lions, Horses, and Liturgical Garb}

The pages of MA 115 preserve four miniatures: the frontispiece facing the beginning of the Gospel of Matthew (fig. 1) and three individual Evangelist portraits (Mark, Luke, and John) prefixed to their respective accounts (figs. $2 \mathrm{a}-\mathrm{c})$. Serving as a visual symbol of the harmony of the Gospels, the frontispiece shows the central figure of Christ within a double circle surrounded by four smaller circles containing the figures of the Evangelists. The placement of the latter within the frame-starting at the upper left, Matthew, Mark, Luke, John-follows the canonical order of the Gospels as listed by Jerome in the preceding Plures fuisse prologue. Jerome further indicates that the Evangelists were prefigured by the Four Living Creatures spoken about by the prophet Ezekiel, and he gives each writer a symbolic face-man (Matthew), lion (Mark), ox/calf (Luke), eagle (John)— that best corresponds to the opening lines of the respective narrative. ${ }^{45}$

Smith, Province and Empire, 169 n. 89; and David N. Dumville, "Breton and English Manuscripts of Amalarius's Liber Officialis," in Mélanges François Kerlouégan, ed. Danièle Conso, Nicole Fick, and Bruno Poulle (Besançon: Université de Besançon, 1994), 205-14.

43 Dumville, "Breton and English Manuscripts of Amalarius's Liber," 212-14.

44 George Demacopoulos, Gregory the Great: Ascetic, Pastor, and First Man of Rome (Notre Dame, IN: University of Notre Dame Press, 2015), 53-56 at 54.

45 St. Jerome, preface to Commentary on Matthew, trans. Thomas Scheck (Washington, DC: Catholic University of America Press, 2008), 55: "The first face of a man signifies Mat- 
The Evangelists, three of whom are identified by name, are portrayed as composite creatures whose human bodies carry the heads of their symbols, evoking the Living Creatures of the prophetic vision. The so-called beastheaded type of the Evangelist portrait, also referred to as "anthropomorphic" or "zoo-anthropomorphic," is by no means unique to Brittany or the period. ${ }^{46}$ The zoo-anthropomorphs have been given a significant amount of scholarly attention, and while questions remain, their further exploration is beyond the scope of the present paper. ${ }^{47}$ The two uniquely Breton features of the illuminations - the mystical-liturgical character of the imagery and the variability in the representation of Mark-have been much less studied, yet they are of great interest. ${ }^{48}$ In the frontispiece, the figures of Christ and the Evangelists wear sacerdotal vestments complete with stoles, the latter being a long, scarf-like liturgical ornament worn by deacons and priests in the celebration of the Mass. The stole became a distinguishing attribute of priestly office: "By the ninth century it was accepted everywhere as a part of

thew, who began his narrative as though about a man. ... The second [face signifies] Mark in whom the voice of a lion roaring in the wilderness is heard: 'A voice of one shouting in the desert: Prepare the way of the Lord, make his paths straight.' The third [is the face] of the calf which prefigures that the Evangelist Luke began with Zachariah the priest. The fourth [face signifies] John the Evangelist who, having taken up eagle's wings and hastening toward higher matters, discusses the Word of God."

46 The earliest examples in manuscript art are found in the Sacramentary of Gellone (Paris, Bibliothèque nationale de France, MS lat. 12048), the Gospels of Maeseyck (Maeseyck, Church of St. Catherine Treasury), and the Orosius manuscript from Laon (Laon, Bibliothèque municipale, MS 137), all dating to the eighth century. One finds these hybrid creatures in the Gospels of Sainte-Croix of Poitiers (Poitiers, Bibliothèque municipale, MS 17) and in the Book of Kells (Dublin, Trinity College Library, MS 58 [A.I.6]), both dating to ca. 800 .

47 The origin of the iconography is uncertain. The zoo-anthropomorphic portrait remained in use for several centuries, appearing at different times in different geographic areas in the West as well as in the East. See Walter W. S. Cook, "The Earliest Painted Panels of Catalonia (IV)," Art Bulletin 8 (1926): 194-234; Zofia Ameisenowa, “Animal-Headed Gods, Evangelists, Saints and Righteous Men," Journal of the Warburg and Courtauld Institutes 12 (1949): 21-45; Crozet, "Les représentations anthropo-zoomorphiques des évangélistes," 182-87; Tania Velmans, Vojislav Korac, and Marica Suput, Rayonnement de Byzance (Paris: Zodiaque/Desclée de Brouwer, 1999), 44, 57, 60; Mary Dockray-Miller, The Books and the Life of Judith of Flanders (Farnham: Ashgate, 2015), 38-43.

48 The mystical-liturgical character of the imagery is discussed most fully by Besseyre, "Une iconographie sacerdotale," and Kitzinger, "Troyes, Bibliothèque municipale, MS 960.” 
liturgical dress for all clergy, and a priest was not empowered to celebrate the Mass without it." ${ }^{49}$ In 2008, Marianne Besseyre published a thorough analysis of this peculiar iconographic detail found in late ninth- and early tenth-century Breton miniatures. ${ }^{50}$ Suffice it to say that the monks of Landévennec appear to have had a heightened interest in the forms and symbolic meanings of liturgical vestments. Besides stoles, one can recognize a high neck scarf, or amice, wrapped around the necks of the Evangelists, a detail very prominent in the individual portraits (see figs. $2 \mathrm{a}-\mathrm{c}$ ) that has somehow escaped scholars' attention. By the late ninth century, all items of liturgical dress acquired a deeper symbolic meaning, which placed a spotlight on the role of priest as the servant of the Gospel. ${ }^{51}$ In his commentary On the Liturgy, Amalarius gives a detailed explanation of the function and symbolism of the church vestments, starting with the first item of liturgical clothing, the amice:

"The amice, which we wrap around our neck, is our first vestment.

For our voice is in our neck, and our use of speech is therefore expressed through our neck. Through the amice we understand vigilance over our voice, which the psalmist spoke about: 'I said: I will take heed to my ways, that I sin not with my tongue. I have set guard to my mouth.' . . . The amice is so called because it surrounds. In this first vestment, the chastisement of our voice is recommended."52

This is followed by the discussion of the figurative and Christological meanings of the liturgical stole: "The stole signifies the sweet and light burden that the Lord speaks about: 'Take up my yoke upon you.'... Through 'yoke' we understand the Gospel. ... Let the deacon recognize,

49 Pauline Johnstone, High Fashion in the Church: The Place of Church Vestments in the History of Art from the Ninth to the Nineteenth Century (Leeds: Maney, 2002), 17. Concerning the origins and forms of ecclesiastical vestments, see Joseph Braun, Die liturgische Gewandung im Occident und Orient (Freiburg im Breisgau: Herder, 1907).

50 Besseyre, "Une iconographie sacerdotale du Christ et des évangélistes," 7-26.

51 Maureen C. Miller, Clothing the Clergy: Virtue and Power in Medieval Europe, c. 800-1200 (Ithaca, NY: Cornell University Press, 2014), 33-35, 55-58.

52 Amalar of Metz, On the Liturgy, 2.17: 453. Amicire [Lat.]: to wrap, to surround. 
in the stole placed around his neck, that he is a servant of the Gospel, but not its commander. The Gospel is Christ." ${ }^{53}$

One could argue that those were perhaps the very points that the monks were expected to recollect every time they opened their illuminated Gospel book in the celebration of the Mass. The themes of the sweet yoke of the Gospel and of the chastisement of voice will come up again in our discussion.

The schematically rendered books, or tablets, held by the Evangelists are inscribed with the words (re)surrexit dominus or surrexit dominus vere. ${ }^{54}$ Slight variation in spelling may have been a way to underscore, as J. J. G. Alexander thought, "that the four Gospel narratives, for all their differences, speak a single eye-witness truth." ${ }^{55}$ Yet, the words also correspond to the opening lines of the antiphons sung during the Holy Week and Easter season celebrations. ${ }^{56}$ The emphasis here clearly falls on the liturgy and the roles of the liturgical ministers.

In his exposition of the Mass in the Liber, Amalarius describes the central ritual of the Church as a dramatic act of liturgical preaching realized through the concerted efforts of priests, lectors, and cantors. He refers to cantors as praedicatores on a par with deacons and priests: "The cantor does the work of a faithful preacher [3.11.13]. . . Through [their] voice they goad their own heart, as well as the hearts of others, to tears and to the confession of sins [3.11.21]." 57

53 Amalar of Metz, On the Liturgy, 2.20.1-2: 461.

54 The variability in the representation of Scripture in early medieval manuscript art (codex, scroll, tablet) and the meanings carried by each format are discussed by Kitzinger, "Troyes, Bibliothèque municipale, MS 960," 35-36, and Charlotte Denoël, "L’Épiphanie du Verbe: Essai d'une typologie formelle des représentations du livre au premier Moyen Âge dans les portraits des évangélistes," in Imago Libri. Représentations carolingiennes du livre, ed. Charlotte Denoël, Anne-Orange Poilpré, and Sumi Shimahara (Turnhout: Brepols, 2018), 15-26.

55 Alexander, Marrow, and Sandler, The Splendor of the Word, 47.

56 James Monti, A Sense of the Sacred: Roman Catholic Worship in the Middle Ages (San Francisco, CA: Ignatius, 2012), 495 n. 243: "The versicle Surrexit Dominus de sepulcbro is traceable to the Antiphonary of Compiègne (France, c. 870)"; 495 n. 244: "The versicle Surrexit Dominus vere is traceable to the Mass antiphonary of Rheinau (Switzerland, c. 800), in which it appears as the Alleluia verse for the Fourth Sunday after Easter."

57 Amalar of Metz, On the Liturgy, 3.11: 77-83. 
In the same way, he calls the lector at Mass a teacher who "should transmit the law of the Lord to his listeners, as if they were just beginning their instruction in the Lord's school." ${ }^{8}$ The work of preaching by liturgical ministers acting as heralds of the good news brings them close to the Four Evangelists, whom Gregory the Great calls praedicatores sancti. ${ }^{59}$ By clothing the figures of the Evangelists in contemporary liturgical vestments, the decorator makes them part of a communal prayer service, thereby linking visible and invisible realms. During the liturgy, when the connectedness to sacred figures is most intensely felt, the Four Living Creatures signifying the Evangelists and the four main events in the story of Christ-incarnation (man), sacrifice (ox/calf), resurrection (lion), and ascension (eagle)can be taken, as Gregory taught, as symbolizing all perfect Christians (perfecti) who follow the way of the Lord. ${ }^{60}$

In his discussion of the monastic culture of the Western Middle Ages, Leclercq notes that the role of the liturgy in monastic life began to expand well before the time of the Carolingian monastic reform, and that the adjustments introduced by the ninth-century reformer Benedict of Aniane simply "ratified this evolution." ${ }^{61}$ As it grew richer and more elaborate in form, the liturgy increasingly engaged monastics in what was aptly described as "the process of meaning-making," by inviting the participants to discover with each repetition ever-deeper meaning in the words of Scripture. ${ }^{62}$ Visual anomalies and enigmas that sometimes appeared in the decoration of the Gospel books used in the liturgy and prayerful meditation did "more than merely attract attention and stimulate curiosity," explains Anne-Marie Bouché; "by remaining open-ended and allusive, they [called] up chains of associations . . . to communicate complex, extended structures of meaning." ${ }^{63}$

58 Amalar of Metz, On the Liturgy, 3.11.6: 73-75.

59 Hom III.16, Grégoire le Grand, Homélies sur Ézéchiel, trans. Charles Morel (Paris: Les Éditions du Cerf, 1986), 140.

60 Hom IV.1-2, Grégoire le Grand, Homélies sur Ézécbiel, 150-53.

61 Leclercq, The Love of Learning, 237.

62 Discussed by Olsen, Reading Matthew with Monks, 241.

63 Anne-Marie Bouché, "Vox Imaginis: Anomaly and Enigma in Romanesque Art," in The Mind's Eye: Art and Theological Argument in the Middle Ages, ed. Jeffrey Hamburger and Anne-Marie Bouché (Princeton, NJ: Princeton University Press, 2006), 306-35 at 311. 
Perhaps the greatest peculiarity of the Landévennec miniatures lies in the interpretation of the symbol of Mark. At first glance, the head of the Evangelist, as depicted in the frontispiece (see fig. 1), is not too different from that of a lion. Yet, the rendering of the head is somewhat ambiguous: the animal's snout is long and narrow, and his lips are thick and curled back. The symbolic portrait of Mark placed at the opening of his Gospel (see fig. 2a) is even more unsettling; the elongated head depicted here bears no resemblance to the lion's, making one think rather of a horse. Such ambiguity in the representation of a conventional symbol can only be intentional and cannot be blamed on the decorator's ignorance of animal morphology; as Laurent has rightfully remarked, the models of Mark's lion were abundant and easy to obtain. ${ }^{64}$ In the portrait, the winged figure of the Evangelist wears a sacerdotal dress complete with a stole, which clearly identifies him as a celebrant. In his left hand, he holds a leafy branch and in his right hand a book or tablet with the inscription surrex dns vere. On the sides of the figure stand stylized plant forms, perhaps representing palm branches.

There exist at least four other examples of Mark depicted with the head of a horse or with ambiguous features, all images originating from Brittany and dating to the late ninth and early tenth centuries. ${ }^{65}$ In at least two of them, the Evangelist wears liturgical garb with a stole (Bern, Burgerbibliothek, Cod. 85, fol. 48v; Troyes, Bibliothèque municipale, MS 960, fol. 43v). It seems that the iconography seeks to substitute the horse for the traditional symbol of Mark, the lion, or more commonly, to combine the two symbols in commemoration of Christ's sacrifice and resurrection. The purpose of modification may have been to clarify and amplify the signification carried by the lion, a hypothesis that will be further developed here.

It was common for early Christian writers and readers to see animals in more than one capacity and thus to give them diverse and often conflicting

64 Laurent, Bretagne et Bretons, 30.

65 Oxford, Bodleian Library, MS Auct. D.2.16, fol. 71v; Bern, Burgerbibliothek, Cod. 85, fol. 48v; Boulogne-sur-Mer, Bibliothèque municipale, MS 8, fol. 42; Troyes, Bibliothèque municipale, MS 960, fol. 43v. 
interpretations. ${ }^{66}$ Early interpreters had, as Jacques Voisenet has put it, the "mentalité de collectionneurs"; in other words, they would endlessly expand the collection of meanings associated with animals for the purpose of making it richer and more valuable. ${ }^{67}$ Based on the representations in the Bible, the roaring lion had variably been interpreted as a symbol of royalty, strength, and justice or as a warning of danger, blood, and impending death. In her analysis of the decoration of the Book of Kells, Heather Pulliam points out that Psalm 22, recited by Christ on the cross, compares unrelenting and cruel persecutors to lions, "They have opened their mouths against me, as a lion ravening and roaring." ${ }^{68}$ To these familiar characterizations of the king of beasts as commanding, fearless, and frightening, early Christian exegetes added allegorical interpretations linking the roaring lion, on the one hand, to Christ and the resurrection, and on the other, to the Evangelist Mark, whose narrative opens with the words from Isaiah $40: 3$ on the voice of one calling in the wilderness.

Gregory the Great in his homilies on the Gospels repeatedly approaches the biblical notion of the voice rising in the desert as representing the powerful voice of a preacher. Commenting on the words of John the Baptist in John $1: 23$, "I am the voice of one calling in the desert," Gregory formulates the essence of John's mission: "He is the forerunner of the Lord's coming and so he is called a voice, since the Father's Word is heard by humans through his ministry. He cries out in the wilderness because he makes known to an abandoned and forsaken Judea the consoling news of its redemption." ${ }^{69}$

Perhaps the most enlightening commentary on the apostolic mission of the Church and on the allegorical meaning of the roaring lion is contained in Gregory's homily on Luke 10:1-7 (PL 1139) addressed to the members of the clergy. Gregory speaks of "the duty of preaching" and of the role of preachers as "heralds of the Judge who is going to come," referring to the

\footnotetext{
66 Jacques Voisenet, Bestiaire chrétien: L'imagerie animale des auteurs du Haut Moyen Âge $\left(V^{e}-X I^{e}\right.$ s.) (Toulouse: Presses universitaires du Mirail, 1994), 316.

67 Voisenet, Bestiaire chrétien, 309.

68 Heather Pulliam, Word and Image in the Book of Kells (Dublin: Four Courts Press, 2006), 139, with a quote from Ps. 22:13.

69 Hom 4 (PL 1099), Gregory the Great, Forty Gospel Homilies, trans. David Hurst (Kalamazoo, MI: Cistercian Publications, 1990), 23.
} 
words in Isaiah 40:3: "The Lord follows his preachers. Preaching comes first, and then the Lord comes to the dwelling places of our hearts; words of exhortation precede, and by means of them Truth is received by hearts. This is why Isaiah addresses preachers: Prepare the way of the Lord, make straight the patbways of our God! .. . We make a way for him [emphasis added] ... when we preach his glory to your hearts, so that he himself, coming afterwards, may enlighten them by the presence of his love."70

In Gregory's reading, the verse from Isaiah, as it is used in the Gospel, is a rallying cry for preachers. Bringing to memory the vivid image of a roaring lion, Gregory teaches that to become an effective preacher, one has to combine the gentleness of the ox with the severity of the lion:

We must then support those we correct, and correct those we support. If one element is missing his actions will lack either zeal or gentleness. When the temple was built, lions and oxen and cherubim were carved on its foundations. . . What do the foundations of the temple represent but priests in the Church?. . . the lions represented the fear of severity, and the oxen the long suffering of gentleness [emphasis added]. Accordingly, neither lions nor oxen were carved on the foundations alone, since the priest must always keep in his heart the virtue of gentleness and the fear of severity. ${ }^{71}$

Given the authority of Gregory's commentaries, the imagery described above may well have been at the origin of the increased attention accorded to the symbol of Mark in Breton gospel illumination. ${ }^{72}$ It appears that the decorators' attention is focused precisely on the symbol of Mark and not on the person of Mark or specifics of his narrative (with the exception of the introductory lines). In Gregory's interpretation, the lion of Mark-through its association with the herald's voice and the base of the temple-becomes the quintessential symbol of a faithful preacher. It is tempting to think that the unifying theme of preaching that characterizes the decoration of MA

70 Hom 19 (PL 1139), Gregory the Great, Gospel Homilies, 134-35, 140.

71 Hom 19 (PL 1139), Gregory the Great, Gospel Homilies, 142-43.

72 Kitzinger notes "a certain emphasis" on Luke in addition to Mark in Breton miniatures; Kitzinger, “Troyes, Bibliothèque municipale, 960,” 36-38. 
115 has found its expression even in the choice of colors for the miniatures. The palette of yellow, blue, purple, and red is remarkably similar to the set of "priestly" colors prescribed for Aaron's vestments in Exodus 28:5, where each color signified a particular virtue, as explicated by Gregory. ${ }^{73}$

The meanings carried by Mark's lion are further expanded and amplified by the addition of the horse. Isidore of Seville in the Etymologies lists some of the "positive qualities" of the horse. In his description of horses, Isidore specifically mentions that "many of them shed tears when their master dies or is killed, for only the horse weeps and feels grief over humans."74 A somewhat similar view of horses as animals capable of foreseeing the future and grieving for man is presented in Adomnán's Vita of Saint Columba, a text well known in Brittany. ${ }^{75}$ Given the liturgical nature of the Landévennec manuscript, one could easily picture a symbolic link between the servant of Christ and a creature emblematic of service, devotion, and compassion. Yet, the above readings cannot reflect the full range of meanings that would have been known to an educated and literary-minded medieval monk.

In her exploration of the meaning of minor decoration in the Book of Kells, Pulliam could not find an easy explanation for the presence of the horse:

Within the Book of Kells, however, the presence of the horse is a curious addition. The word "horse" appears in the Vulgate Bible in forty-nine places. In only two instances, Zechariah 10:3, where the good man is compared to the "horse of his [God's] glory," and Isaiah 63:13 where Moses is compared to a horse in the wilderness "that stumbles not," does the horse have positive connotations. In every other occurrence, the horse takes on a negative role, typically

73 Gregory the Great, Pastoral Care, cited in Miller, Clothing the Clergy, 53-54. For colors constituting the traditional Insular and Merovingian palettes, see Michelle P. Brown, The Book of Cerne: Prayer, Patronage and Power in Ninth-Century England (London: The British Library, 1996), 70.

74 The Etymologies of Isidore of Seville, trans. Stephen Barney, W. J. Lewis, J. A. Beach, and Oliver Berghof (Cambridge: Cambridge University Press, 2006), XII.1.43: 249.

75 Adamnan, Life of Saint Columba, Founder of Hy, ed. William Reeves, Book III (Edinburgh: Edmonston and Douglas, 1874), 96-97. 
either as a symbol of lust combined with willful ignorance or of man's misplaced faith in his own strength. ${ }^{76}$

Clearly, the answer that we seek, the one that would explain the link between the Evangelist and the horse, is not to be found in the Bible, at least not directly. But one can find it in Gregory's Moralia, in the sections discussing the essential qualities of preachers. Reflecting on the allegorical meaning of the horse in Job 39, Gregory says:

Let us behold the horse, how he already draws through his nostrils a breath from those things which as yet he sees not; let us behold with what glory he is elated, when he is waiting for things that are yet to come. ${ }^{77}$

By the name "horse" is understood each holy preacher, as the Prophet witnesses, who says: Thou sentest Thine horses into the sea, disturbing many waters [Hab. 3:15]. For the waters, in truth, lay quiet, because the minds of men lulled to rest a long while, beneath the torpor of their sins. But the sea was disturbed by the horses of God; because, when holy preachers had been sent, every heart which was benumbed with fatal security was alarmed by the shock of wholesome fear. In this place, therefore, a holy preacher is understood by the name "horse," when it is said to blessed Job; ${ }^{78}$

The horse of God, therefore, fears not the blast of the trumpet, because the illustrious preacher, having despised the powers of the

76 Pulliam, Word and Image, 161.

77 Saint Gregory the Great, Morals on the Book of Job, vol. 3 (Oxford: J. H. Parker, 1844-50; www.lectionarycentral.com), 31.XXVI.52.

78 Gregory the Great, Morals, 31.XXIV.43. 


\section{Barbashina: Evangelist Portraits in the Harkness Gospels}

world, fears not the sounds of any threats. . . . He can be killed, he cannot be overcome. ${ }^{79}$

The horse, therefore, says "Vah," on hearing the trumpet, because every bold preacher, when he thinks the contest of suffering approaching, exults in the exercise of virtue and is not alarmed at the peril of the contest, because he rejoices in the triumph of victory. ${ }^{80}$

Having described the horse as a symbol of steadfast and fearless preachers, Gregory notes that one may recognize the features of the Horse of God in "any soldier in the spiritual contest." ${ }^{11}$ The statement makes the symbol applicable not just to the Evangelists, as preachers and soldiers of Christ par excellence, but to any righteous Christian. The comparison drawn between the courage and fortitude of the servant of Christ and the strength and fearlessness of the lion brings to mind one of the key points in Gregory's description of the horse, and thus one should not be surprised at finding the two animals tied together in the symbol of Mark: "the fearlessness of a righteous man is rightly compared to a lion, because when he beholds any rising against him, he returns to the confidence of his mind; and knows that he overcomes all his adversaries, because he loves Him alone, Whom he cannot in any way lose against his will." ${ }^{2}$

The most straightforward depiction of Mark's symbol as a horse appears on folio 42 of the late ninth-century Breton Gospels of the so-called Landévennec group of manuscripts (Boulogne-sur-Mer, Bibliothèque municipale, MS 8; see fig. 3). ${ }^{83}$ The "zoo-anthropomorphic" portrait shows the Evangelist with the head of a horse; his neck is covered by an amice and his left hand holds a rectangular object, which could be a book or a tablet. But

79 Gregory the Great, Morals, 31.XXXII.67-68.

80 Gregory the Great, Morals, 31.XXXIII.69.

81 Gregory the Great, Morals, 31.XLV.91.

82 Gregory the Great, Morals, 31.XXVIII.55.

83 See note 1. Digitized images are available at https://bvmm.irht.cnrs.fr/. 
the most curious detail here is the oddly shaped ornament plastered onto the front of the amice over the neck of the Evangelist. The abstract, tile-like piece is red in color, suggesting that it comes from the red-colored page held by the Evangelist (which shows a corresponding "hole" in the shape of the ornament). One can hypothesize that it was a way for the decorator to remind priests and lectors that the voice of the preacher comes from the Gospel, and that "the chastisement of our voice is recommended." ${ }^{84}$ As a closing note, I would like to bring in what seems to be the last missing piece of the puzzle, Gregory's description of the voice of the horse, that is, of the voice of preaching:

But what is meant by the Lord's saying, that He first gives strength to this horse, and afterwards surrounds his neck with neighing? [Vulgate, Job 39:19] For by neighing is set forth the voice of preaching. But every true preacher receives, first, strength, and afterwards neighing, because, when he has first extinguished sin in himself, he then attains to the voice of preaching, for the instruction of others. ... And we must observe, why neighing, which is doubtless uttered inwardly through the throat, is said to be placed round the neck of the horse, that is, to be drawn in a circle outwardly. Because, namely, the voice of preaching emanates from within, but encircles from without. For as it rouses others to good living, it binds also the conduct of the preacher to good deeds, in order that his conduct may go not beyond his words, nor his life contradict his speech. ... Hence is it, that a collar is given as a reward to men who fight with all their power. ${ }^{85}$

\section{Conclusion}

Artistic ideas realized by monastic decorators in the illumination of early biblical manuscripts derived for the most part from reading, authoritative

84 Amalar of Metz, On the Liturgy, 2.17: 453.

85 Gregory the Great, Morals, 31.XXIV.44. 
commentaries, and liturgical experiences. Logic suggests that symbolic representations occurring in early medieval Gospels, however strange they might look to us today, were meant to be illuminating and easily comprehensible to a knowledgeable reader, and thus they had to be based on biblical descriptions, prevailing concepts, and familiar exegetical material. The images might look strange to us, but most were not regarded as controversial at the time. For a contemplative, liturgical community of medieval monks brought up on Christian commentaries and the idea of the multiplicity of meaning, the horse-taken as an allegory of the fearless and steadfast preacher-could make a perfect alternative symbol for the Evangelist.

For monasteries in the West, the ninth century - an age that ushered in significant changes in the way of life and practice-was characterized by a growing interest in the liturgy and liturgical symbolism. The monks of Landévennec do not seem to be much different in that regard. Their keen interest in the symbolic meanings of the ritual and liturgical dress is reflected in the manuscript illuminations, while their desire for dramatic element is revealed in the addition of melodic ornamentation to the lines of text used in the key parts of the service. ${ }^{86} \mathrm{New}$ information obtained through recent archeological and historical investigations suggests that the monks, while proud of their heritage, were eager to combine the old ways with the new, and thus had much more in common with their contemporaries than is commonly believed. The current state of evidence does not give credence to the idea that Landévennec was a bastion of resistance against Carolingian influence, nor does it provide any hints as to why the monks would have wanted to boldly display such opposition.

The iconographic choices made by the decorators of the Harkness manuscript appear to have been influenced, at least in part, by the ideas of the Carolingian liturgist Amalarius of Metz, whose allegorical interpretations of the ritual and sacred vestments were becoming increasingly popular

86 The neumes have been identified as Breton and of roughly the same period as the manuscript. Whether they were added when the manuscript was still at Landévennec, or early in the tenth century when it was brought to England, is not entirely clear. See Morey, Rand, and Kraeling, The Gospel Book of Landévennec, 4, 14-15; Huglo, "Les Évangiles de Landévennec," 247-49; and Hartzell, “The Early Provenance of the Harkness Gospels,” 85-97. 
in the ninth century. But it was perhaps the vivid imagery of Gregory the Great's biblical exegesis that prompted the most singular elements in Breton gospel illumination. In Gregory's commentaries, the roaring lion of Mark becomes firmly associated with the voice of preaching. As for the allusions to the horse in Breton depictions of the symbol, I suggested here that the decorators drew inspiration from Gregory's metaphorical description of the preacher as the Horse of God given in the Moralia on Job 39. By amplifying the meaning carried by the Evangelist symbol, the decorators evidently sought to elicit greater response from a receptive audience. The innovative iconography united the lion and the horse in celebratory remembrance of Christ's sacrifice and resurrection and glorified in the image of the Evangelist the holy preacher, the devoted and fearless Horse of God. This bold artistic experiment proved short-lived, having sparked little enthusiasm outside of its geographical area. Tellingly, in one of the manuscripts that landed in England, the images, though largely preserved, were eventually supplemented with more conventional artwork. ${ }^{87}$

But as our two commentators might say, the miniatures have served their purpose well. "Letters are copied," Amalarius said, "so that, through them, what has been lost by forgetfulness might be committed to memory. Similarly, we recall through an image what can be committed to our memory within." ${ }^{\prime 8}$

87 Oxford, Bodleian Library, MS Auct. D.2.16, 72v, 146r, https://digital.bodleian.ox.ac.uk; noted by Alexander, Medieval Illuminators and Their Methods of Work, 77, 82, and 168 n. 34. 88 Amalar of Metz, On the Liturgy, 3.11.22: 83. 